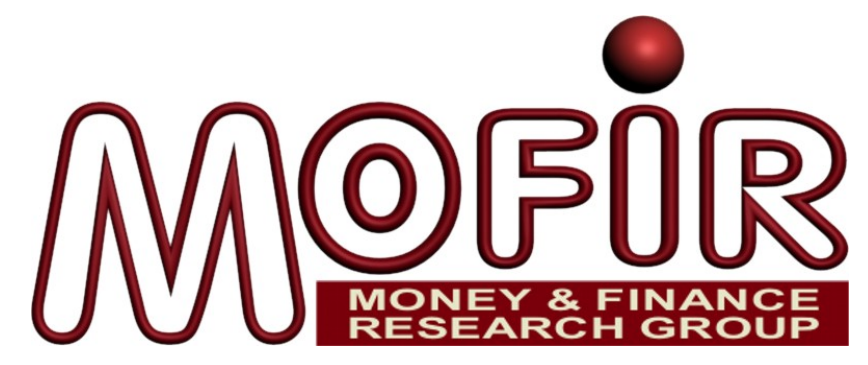

\title{
The Global Crisis in Low- and Middle- InCOMe Countries: How THE IMF RESPONDED
}

\author{
Andrea F. Presbitero \\ Università Politecnica delle Marche, Department of Economics \\ MoFiR \\ CeMaFiR
}

Alberto ZazZAro

Università Politecnica delle Marche, Department of Economics

$M o F_{I} R$

CFEPSR

MoFiR working paper $n^{\circ} 35$

February 2010 


\title{
The Global Crisis in Low- and Middle-Income Countries: How the IMF Responded
}

\author{
Andrea F. Presbitero \\ Alberto Zazzaro*
}

February 23, 2010

\begin{abstract}
Developing countries are the least to blame for the outbreak of the financial crisis, but they are destined to suffer the most dramatic and long-lasting consequences. This chapter focuses on the early responses of the International Monetary Fund to the present crisis in low- and middle-income countries. The IMF lending policy has been harshly criticized for being sensitive not only to the fundamental imbalances in the economic conditions of borrowing countries, but also to their lobbying capacity and to political-economy interests of the IMF's major shareholders, i.e., the USA and G-7 countries, which dominate the decision-making process and the Fund's view of good economic policies. Preliminary analysis of the 2008 and 2009 IMF arrangements shows that, notwithstanding the recent changes in the lending framework and the severity of the global crisis, the Fund's credit allocation is still mainly driven by the strategic interests of Western countries, instead of the macroeconomic conditions of recipients.
\end{abstract}

JEL Classification: F33, F34, F35, O11

Key words: Global crisis, IMF programs, Washington Consensus, growth.

*Andrea F. Presbitero (corresponding author), Department of Economics - Università Politecnica delle Marche (Italy), Money and Finance Research group (MoFiR) and Centre for Macroeconomic and Finance Research (CeMaFiR). E-mail: a.presbitero@univpm.it; personal webpage: http://utenti.dea.univpm.it/presbitero/. Alberto Zazzaro, Department of Economics - Università Politecnica delle Marche (Italy), Money and Finance Research group (MoFiR) and Centro per la Formazione in Economia e Politica dello Sviluppo Rurale (CFEPSR). E-mail: a.zazzaro@univpm.it; personal webpage: http://utenti.dea.univpm.it/zazzaro/. The authors wish to thank Marco Arnone, Luigi Bosco and the participants at "The Global Crisis" Conference (University of Siena, 26-27 January 2010) for useful suggestions. 
"I feel cheated as I wonder how economic problems somewhere in America can make my cash crop suffer here in Malawi. It's a shame that I cannot boil and eat it."

A Malawian cotton farmer (Green, King and Miller-Dawkins, 2010).

\section{Introduction}

Originating in the US mortgage market, the financial crisis rapidly spread across rich, emerging and poor countries and turned itself into the worst economic turmoil worldwide after the Great Depression of 1929. Although the crisis is far from over, many emergingmarket countries have now started growing close to pre-crisis rates, while OECD countries have resources and instruments to cope with it and mitigate its effects on displaced workers and vulnerable people. By contrast, poor countries are still well below their trend of output growth and lack the appropriate tools to deal with these multiple external shocks. Thus, the poorest people in the poorest countries, those who are the least responsible for the crisis, end up being the most exposed to the global recession: not only do they lack sufficient safety nets for immediate help but also, more importantly, they are going to be dramatically affected in the long run by the likely reduction in social spending. The United Nations (2009) stresses that the financial crisis is jeopardizing the achievements of the Millennium Development Goals: poverty ratios, indicators of hunger, child malnutrition, gender equality and unemployment all worsened in 2008. A new generation of poor might not benefit from the recent (limited) progress in education and health, with severe consequences for individuals and local communities. The most recent World Bank estimates, for example, suggest that lower growth rates in developing countries, due to the twin food/fuel and financial crises, would trap an additional 89 million people in poverty, to be added to the 130-155 million people pushed into poverty in 2008 (World Bank, 2009). Besides, the economic and food crises have increased the number of the undernourished worldwide to more than one billion people, the highest level since 1970 (Food and Agriculture Organization, 2009). As the World Bank President Robert Zoellick admits, the consequences on infant and child mortality could be dramatic:

"we estimate that as a result of the sharply lower economic growth rates, between 200,000 and 400,000 more children a year may die, and that's out of a total of about 1.4 to 2.8 million children that perish each year" (Zoellick, 2009).

In the same vein, the managing director of the International Monetary Fund (IMF), Dominique Strauss-Kahn has not hesitated to say himself

"deeply concerned by the potential humanitarian costs of this crisis. [...] starting from what is only a financial crisis, we may at the end have much bigger consequences than only income and growth consequences. For these reasons, low-income countries have to safeguard the funds they have for education and infrastructure, while boosting safety nets to protect the most vulnerable" (Strauss-Kahn, 2009, pp. 9-10). 
To address this new dramatic socio-economic emergency, the rich world and the International Financial Institutions (IFI) should reshape their policy agenda, focusing much more attention and providing more resources and assistance to low-income countries. Some recent steps have been made by the IFI, such as the "Vulnerability Fund" sponsored by the World Bank to lobby industrialized countries to divert the 0.7 percent of their stimulus packages in financial assistance to developing countries, the IMF Poverty Reduction and Growth Trust, and the call for a temporary debt moratorium on all official debt of low-income countries (UNCTAD, 2009). While commendable and encouraging initiatives, they are still not enough. As Strauss-Kahn emphatically declared,

"it's clear that the financing needs are substantial, and they are very urgent. [...] the international community [has] to provide the financing the most vulnerable countries need to preserve their hard-earned gain, and also to prevent a humanitarian crisis. Of course, the primary responsibility to me lies with bilateral donors who must ensure that the aid flows are scaled up, not down" (Strauss-Kahn, 2009, p. 14).

That said, the recent G-8 summit in L'Aquila in July 2009 confirmed the usual "abundance of promises and commitments, without sufficient details and clear mechanisms that would ensure effective implementation" (De Rienzo, 2009). The 2005 Gleneagles pledges to double aid to Africa were re-stated, but it is still unclear when the promised additional resources will become available, especially now that the crisis is severely affecting government budgets. However, the threat of a new debt crisis, political instability and social unrest which generally follow severe economic downturns in low-income countries, not to mention the increase in transnational crime, should be sound and self-interested arguments to urge rich countries to scale up their involvement in international aid programs.

In this chapter, we will focus on the early responses of the International Monetary Fund to the present crisis in low- and middle-income countries. The IMF lending policy has been harshly criticized by left-wingers, for imposing on borrower countries uniform, undue, intrusive, ineffective and ideological austerity programs, and by right-wingers, for encouraging moral hazard on the part of both borrowing countries and other private creditors (Bird, 2007; Dreher, 2009). In both cases, however, the blame on the Fund is that its lending decisions are sensitive not only to the fundamental imbalances in the economic conditions of borrowing countries, but also to their lobbying capacity and to political-economy interests of the IMF's major shareholders, i.e., the USA and G-7 countries, which dominate the decision-making process and the Fund's view of good economic policies (Fratianni and Pattison, 2005). Very recently, Stiglitz (2010) criticized the G-20 reaction to the crisis in developing countries and the allocation of new funds to the IMF on the ground that "little of the money given to the IMF was likely to get to the poorest countries [... and that] one of the impetuses for the Western European governments providing funds was that they hoped that the IMF would help Eastern Europe". Moreover, strategic interests seem to be at stake also in the IMF loan to Iceland, whose approval was held up until the agreement with the UK and Dutch governments on the repayment of the Icelandic main banks' private debt.

All in all, empirical evidence tends to corroborate this view, indicating that the IMF lending programs respond to reasons other than the current account deficits, low official 
reserves or low growth prospects in the borrowing countries, and that IMF members economically and politically closer to G-7 countries receive larger loans with fewer conditions (Bird and Rowlands, 2001; Barro and Lee, 2005; Harrigan, Wang and El-Said, 2006; Dreher and Jensen, 2007). Our objective is to provide some preliminary evidence on the determinants of IMF lending to low- and middle-income countries in 2008-2009. In particular, we are interested in assessing whether resources have been allocated according to the severity of the crisis and to what extent the IMF response to the crisis has been influenced by the strategic interests of its major shareholders.

The rest of the chapter is organized as follows. In the next Section, we discuss the effects of the crisis in low- and middle-income countries. In Sections 3 and 4, we discuss the role of the Fund in these countries and its response to the crisis in terms of new lending facilities and new loans. In Section 5, we analyze the factors shaping IMF lending during the crisis and in Section 6 we draw some preliminary conclusions.

\section{The global crisis in low- and middle-income coun- tries}

The 2007-2009 financial crisis spread from a small sector of the U.S. financial industry all over the globe in the space of a few months. According to the World Economic Outlook (WEO) database, world GDP should contract by more than one percentage point in 2009 and grow by $3.1 \%$ in 2010 (Figure 1). These rates are significantly lower than those estimated by the IMF in April 2008, just before the global outbreak of the crisis. The difference between the pre-crisis and the latest projections, which can be considered a proxy of the extent of the crisis, is similar in advanced and developing countries. However, because of different initial conditions, real GDP in 2009 shrank by $3.6 \%$ in G-7 countries and increased by $1.7 \%$ in emerging and developing countries. The most severe output contraction, both in absolute terms and with respect to the pre-crisis estimates, regards the former Soviet Republics (CISs) and the Central-Eastern European (CEE) countries, while developing Asian countries (including China) have suffered the least from the crisis and are projected to grow by $6.2 \%$ and $7.3 \%$ in 2009 and 2010 . Finally, the poorest Sub-Saharan African countries slowed by more than 5\% with respect to the April 2008 estimates. Slower growth rates, together with a sharp decline in fixed investment growth which fell from 13.7\% in 2007 to an estimated 1.3\% in 2009 (World Bank, 2010), have caused a dramatic increase in unemployment rates worldwide (International Labour Office, 2010). Job losses would particularly target migrant workers in developed economies, spurring reverse migration and lowering remittances, and might be especially harmful in poor countries, where workers are mainly employed in the informal sector and lack adequate savings to fall back on and social protection and safety nets to catch them.

The financial crisis reached poor countries, especially in Sub-Saharan Africa, when they were still affected by the food crisis (World Bank, 2009) ${ }^{1}$. Poor countries' vul-

\footnotetext{
${ }^{1}$ International commodity prices increased substantially from 2005 to mid-2008, when they collapsed. However, since 2009 prices have again followed an upward trend and are currently well above their pre-crisis level (see http://www.imf.org/external/np/res/commod/index.asp). Furthermore, local food prices in many countries have not fallen: according to the most recent survey conducted by the World Food Program (2010), in $73 \%$ of the countries monitored, the overall cost of the food basket is more
} 
Figure 1: The Global Crisis

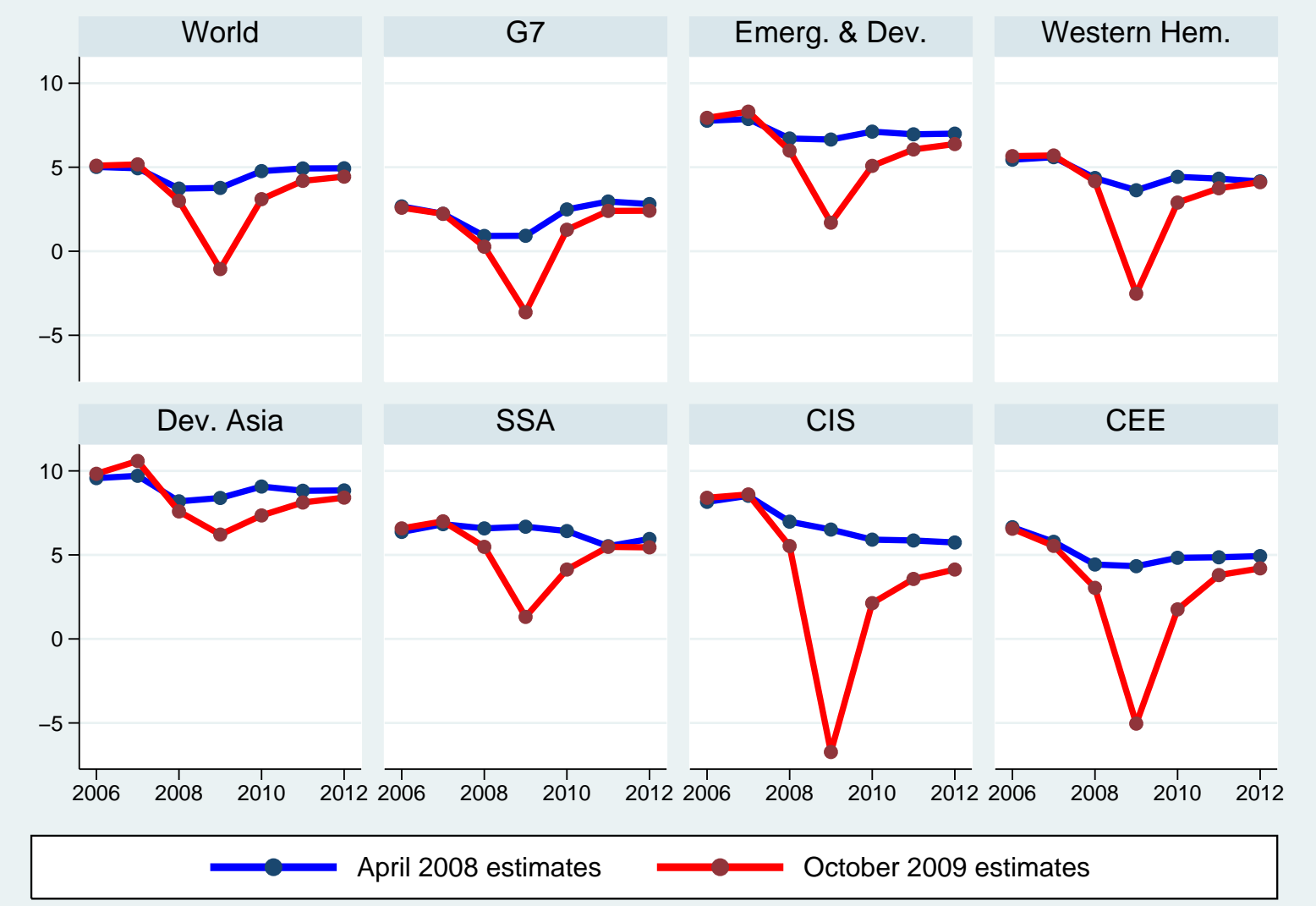

Notes: Elaborations on World Economic Outlook datasets (April 2008 and October 2009). WorLD includes 173 countries; G7 includes Canada, France, Germany, Italy, Japan, United Kingdom, United States; Emerg. \& Dev. is the group of 142 emerging and developing countries; WeStern Hem. is the group of 32 Latin-American and Caribbean countries; Dev. AsIA is composed of 23 developing Asian countries; SSA is the group of 45 Sub-Sahara African countries; CIS is the group of 13 Commonwealth of Independent States (Mongolia is included only in 2009 estimates); CEE is the group of 14 Central and Eastern European countries. See the World Economic Outlook database for further information.

nerability to a collapse in industrialized countries' output is due to their extraordinary dependence on volatile resources, such as exports of primary commodities, private capital inflows, remittances and foreign assistance (Mold, Paulo and Prizon, 2009; International Monetary Fund, 2009d; World Bank, 2009; Presbitero, 2009).

World trade flows declined by more than $12 \%$ in 2009, while oil and primary commodity prices plummeted by nearly $70 \%$ in the second half of 2008 and $50 \%$ in the first quarter of 2009, before rebounding from March 2009. A number of low-income countries have experienced from lower export demand (-16\% in 2009) and swings in the terms of trade (International Monetary Fund, 2009e). Mineral- and oil-exporters registered the worst downturn: average annual growth rate in Angola and Equatorial Guinea, for example, declined from more than $16 \%$ during $2004-2008$ to $0.2 \%$ and $-3.4 \%$, respectively

than $20 \%$ above the 5 -year average. 
in 2009. By contrast, countries specialized in agricultural exports, such as Malawi and Uganda, registered above-average growth (United Nations, 2010) ${ }^{2}$.

The liquidity crisis which affected industrialized countries in October 2008 rapidly froze-up global financial markets, dramatically increasing the cost and availability of finance. The spread paid by commercial and sovereign borrowers in emerging markets skyrocketed from around 180 basis points at the end of 2007 to more than 1,000 basis points at the peak of the crisis, before declining to around 300 bps in January 2010 (World Bank, 2010). In addition, financial inflows contracted from more than $8 \%$ of GDP in 2007 to about $2.5 \%$ in 2009 and are projected to slightly rebound to $3 \%$ of GDP in 2010. African countries were prevented from raising any money issuing international bonds in 2008, just after the first success in Eurobond issuances in 2007 (International Monetary Fund, 2009b) ${ }^{3}$, while Turkey and the Philippines had to wait until January 2010 to collect 3.5 billion of US dollars in international bond markets (World Bank, 2010).

A further reduction in financial flows to low- and middle-income countries has been experienced through the domestic credit market, dominated by foreign banks ${ }^{4}$. In downturn periods, large multinational banks tend to cream-skim their customers to the detriment of local small borrowers (Berger, Klapper and Udell, 2001; Detragiache, Tressel and Gupta, 2008; Gormley, 2010) and drain resources towards the home country via internal capital markets (Peek and Rosengren, 1997; Van Rijckeghem and Weder, 2003). In fact, on aggregate, loans of foreign-owned banks contracted by $13.6 \%$ in the second semester of 2008, more than three times the contraction registered by domestic banks, even if there are significant differences across countries, with foreign banks acting as stabilizers in the Middle East and, partially, in Latin America (World Bank, 2010) . $^{5}$

Negative trends are also observed in foreign direct investments (FDIs) and remittances. After six years of uninterrupted growth, FDIs in developing countries fell to about 406 billion of US dollars in 2009, 35\% less on an annual basis, and do not yet show any sign of recovery (UNCTAD, 2010; World Bank, 2010). A number of countries will have to scale down large infrastructure projects, especially natural resource abundant countries, where a number of exploration and exploitation projects, started in response to the surge in commodity prices, will be postponed. With regard to remittances, because of rising unemployment in Western countries, migrants are increasingly unable to send money back home, with dramatic consequences for their households ${ }^{6}$. According

\footnotetext{
${ }^{2}$ The large fall in tourism revenues (-7\% in the first half of 2009 , according to the World Tourism Organization) represents another source of vulnerability for developing countries, especially for small island states, some Caribbean and Latin America countries, such as Mexico, and CEE countries.

${ }^{3}$ Ghana, in example, issued an oversubscribed USD 750 million Eurobond in September 2007, but had to postpone plans for a $\$ 300$ million issue because of poor global market conditions. Similar patterns are observable in Tanzania, which in December 2009 renewed its intention to issue Eurobonds for 500 million Euros in 2010 to finance infrastructure development; in Kenya, whose rating was downgraded also because of ethnic violence and political instability after the last elections; and in Uganda.

${ }^{4}$ According to World Bank data, the share of foreign-owned banking assets is about $50 \%$ or more in Sub-Saharan Africa and Europe and Central Asia, and more than one third in Latin America. See the World Bank website at: http://go.worldbank.org/X23UD9QUX0.

${ }^{5}$ Financial markets are also hit by the crisis: the deterioration in the functioning of US and European interbank markets forced investors to deleverage and reduce their positions in developing countries' bond, money and equity markets.

${ }^{6}$ Anecdotal testimonies are numerous:"[My relatives in the US] are unable to send me money because the job opportunities are not there any more. Their support is a huge contribution to the family here
} 
to World Bank estimates, after years of double-digit growth rates, the crisis will induce a contraction in international remittances of about 6\% in 2009 (Ratha, Mohapatra and Silwal, 2009).

Finally, the severity of the crisis in poor countries is harshened by national governments' lack of appropriate tools to tackle the crisis. Apart from a few poor countries which were able to accumulate international reserves or reduce public debt in recent years, the majority of developing and emerging countries have scarce resources and "limited fiscal space" to fund any fiscal stimulus (Reinhart and Reinhart, 2009). Moreover, a fiscal expansion may not be particularly effective due to small fiscal multipliers (Ilzetzki and Vegh, 2008) and limited access to international capital markets and thin domestic financial markets, which might lead to a crowding-out of private investment (Berg et al., 2009). Finally, in developing countries with a recent record of central bank independence, a fiscal expansion could result in financing deficits with money creation, losing the hardgained credibility and threatening the pursuit of price stability (Reinhart and Reinhart, 2009).

Given the stricter access of developing countries to private international financial markets, foreign aid should increase its role acting as a sort insurance mechanism (Pallage, Robe and Bérubé, 2006). However, notwithstanding the several pronouncements by IFI and donors, past experience suggests that official development assistance (ODA) is not likely to be scaled up as a response to the crisis (Roodman, 2008; Frot, 2009; Dang, Knack and Rogers, 2009). The preliminary IMF estimates on foreign aid show a decline with respect to 2008, while anecdotal evidence on donors suggests that some of them, such as Austria, Ireland and Italy, are already reducing their disbursements, while others are "front-loading" their aid efforts, meaning that they are borrowing from future years to keep steady now, so that aid could fall further after $2009^{7}$.

\section{The IMF in low- and middle-income countries}

In view of the sudden decrease in exports, foreign aid, capital flows and of the limited room for countercyclical policies, a critical role in tackling the crisis in poor countries is going to be played by the World Bank and the International Monetary Fund.

As established at the Bretton Woods conference in 1944, the primary mandate of the IMF is to offer short-term financial assistance in member countries plagued by balanceof-payment deficit and official reserve problems, and to promote structural adjustments in order to restore external balance stability, considered as a prerequisite for sustained economic growth. Unlike the World Bank and other regional development banks, the IMF is not intended to fund specific long-term development programs and so its involvement in low- and middle-income countries has been traditionally rather moderate. However, starting from the collapse of the Bretton Woods system, the importance of the developing world in IMF lending policy has greatly increased and is sanctioned by the establishment of the Poverty Reduction and Growth Facility (PRGF) in September 1999.

because it helps us to support children in school and pay medical bills when one is sick" (Green, King and Miller-Dawkins, 2010)

${ }^{7}$ The US budget for fiscal year 2011 indicates a reduction in overseas aid to limit the explosion of US debt. By contrast, even with a shrinking economy, the UK government has left the aid budget unchanged at GBP 9.1 billion for 2010, as projected in 2007. 
The IMF loans are provided under an "arrangement" which stipulates specific policies which the country agrees to implement in order to resolve its balance of payments problems. This agreement (the "letter of intent") includes the heavily criticized conditionalities, introduced with the primary aims of safeguarding the revolving character of IMF loans and inducing governments to pursue unpopular reforms (Dreher, 2009). In fact, conditional loans materialize in a widely-accepted decalogue of market-oriented reforms commonly known as the "Washington Consensus": trade and foreign direct investment liberalizations, privatization, deregulation, fiscal discipline and exchange rate devaluation (Williamson, 1990, 2004; Marangos, 2009). In lights of the failed experiences of the IMF market-fundamentalist policies in Latin America, Africa and Asia during the 1980s and 1990s, and the complex transition of former communist countries to free markets $^{8}$, the Fund's lending strategy came under attack and received several influential criticisms because it was unable to match the new expansionary and poverty-fighting roles with the rigor of the conditional programs (International Financial Institution Advisory Commission, 2000; Stiglitz, 2002).

In response to these criticisms, the IMF started a downsizing and re-focusing process, with a shrinking budget and a minor role in the international policy field. The number of its loans substantially decreased and its agenda re-focused on poverty reduction. Fund conditionality also underwent a strong review process and came out streamlined and more flexible.

The reassessment of the role of the Fund in the global economy was still in progress in the wake of the financial crisis, which is acting as an exogenous shock forcing the IMF to speed up its reform process. This would not be a novelty in the Fund's history which, as Bird (2007, pp. 687-688) claims, "could be presented as responding to a series of events that were largely unanticipated". The global financial crisis puts the Fund back at center stage. The IMF reacted very quickly to the unfolding of the crisis: it established new emergency credit lines and was able to boost its budget at the G-20 London meetings. As a result, the role of the Fund in low-income countries is greater than ever. On the one hand, this should be good news for the world's poor, since they are going to receive more resources and assistance, and easier than in the past. On the other hand, the changing role of the Fund raises some concerns on its capacity to address world poverty and to foster economic growth in developing countries, both with respect to the allocation of its growing resources and the macroeconomic effects of its loans. Although it is too early to draw any sensible conclusions on the latter, we present some initial evidence on the targeting of IMF loan programs in the aftermath of the global crisis.

\section{New lending facilities and post-crisis loans}

With the onset of the crisis the IMF expanded its role in emerging and developing countries, increasing its lending capacity and undergoing a significant reshape of its lending instruments. Following the April 2009 G-20 summit in London, an allocation of Spe-

\footnotetext{
${ }^{8}$ Empirical evidence tends to indicate that the number of conditions and their degree of implementation have no, or low, positive effects on the economic performance of borrower countries (Dreher and Vaubel, 2004; Nsouli, Atoyan and Mourmouras, 2006; Dreher, 2006; Hajro and Joyce, 2009; Dreher and Walter, 2010)
} 
cial Drawing Rights (SDR) equivalent to USD 283 billion was approved in August 2009 and existing borrowing arrangements were expanded and renewed, increasing the Fund's lending capacity to USD 750 billion. The bulk of additional resources, however, target industrialized and emerging markets: only USD 110 billion will go to developing countries, with about USD 20 billion to low-income countries ${ }^{9}$.

Apart from increasing its lending capacity, the economic crisis and the subsequent higher demand for funds have forced the IMF to undertake a substantial revision of its lending instruments, traditionally distinguished between non-concessional and concessional loans. Low-income countries can borrow at concessional interest rates (usually equal to $0.5 \%$ ) through the Poverty Reduction and Growth Facility (PRGF) and the Exogenous Shocks Facility $(\mathrm{ESF})^{10}$. Other member countries, instead, access loans at market rates through Stand-By Arrangements (SBAs), established in 1952 and widely used to disburse the largest loans, and the Extended Fund Facility (EFF), established in 1974 primarily for longer-term needs ${ }^{11}$.

The IMF lending framework was overhauled to help developing countries cope with the crisis (for a more detailed discussion see the IMF website and Presbitero (2009)). Emerging markets can benefit from a new lending facility, the Flexible Credit Line (FCL) established in March 2009, from a more flexible SBA with fewer structural conditions, from the doubling of non-concessional loan access limits to 200 of the IMF quota, and from a modernization of conditionality towards country-specific targets and pre-qualification criteria (ex-ante conditionality). In particular, the FCL is a precautionary instrument intended for countries with very strong fundamentals, policies, and a track record of policy implementation. Because of these rigid pre-conditions, it is not burdened with traditional ex-post or ongoing policy conditionality. Regarding the IMF lending in low-income countries, the Exogenous Shock Facility (ESF), originally created to provide financial support to countries facing an exogenous shock, was modified in September 2008 and later in April 2009 in order to made it faster to access and easier to use.

A more comprehensive and important step was taken on July 2009, when the Executive Board of the IMF approved the proposal to establish the Poverty Reduction and Growth Trust (PRGT) instrument, replacing and expanding the previous PRGF-ESF Trust. The new trust includes tools to provide flexible medium-term support, as well as instruments designed to meet countries' short-term precautionary and emergency needs. Besides, the focus on growth and poverty alleviation will be strengthened and the IMF will provide exceptional interest relief to countries most severely affected by the global crisis.

In Table 1, we report the list of 41 IMF lending arrangements in place at November 30, 2009 and started since $2008^{12}$. Apart from the two SBAs approved for Hungary and

\footnotetext{
${ }^{9}$ Similarly, the World Bank is undertaking a number of reforms to increase and speed up its assistance and lending to LIC. Between July 2008 and June 2009, the World Bank committed USD 58.8 billion to help developing countries struggling with the global crisis.

${ }^{10} \mathrm{IMF}$ concessional lending to poor countries started in the mid-1970s through the Trust Fund and continued in 1986 and 1987 with the establishment of the Structural Adjustment Facility (SAF) and the Enhanced Structural Adjustment Facility (ESAF), which was replaced by the PRGF in 1999 to stress poverty reduction and the participatory, country-led mechanism of reforms.

${ }^{11} \mathrm{IMF}$ also provides emergency assistance to countries that have experienced a natural disaster or are emerging from conflict.

${ }^{12}$ As of November 30, 2009, other countries have an IMF loan arrangement in place which started
} 
Iceland in November 2008, all the new lending arrangements were signed with low- and middle-income countries. Out of the USD 177 billion agreed, however, only two percent goes to poor countries under the PRGF and ESF programs, although these countries account for $5.2 \%$ of the GDP and for $35 \%$ of the population of the whole sample of countries on IMF programs. In addition, concessional loans are smaller and on average, if we exclude the striking exception of Liberia, account for only 2.4 percent of GDP. By contrast, the average SBA accounts for $7.6 \%$ of the recipient country's GDP, with the largest share, above ten percent, for the two high-income countries, Hungary and Iceland. The three countries with access to the FCL - Mexico, Poland and Colombia - have a total credit outstanding of around USD 84 billion, equal to about $4.5 \%$ of national output.

The largest loan, in absolute terms and in the history of IMF arrangements, is the precautionary FCL agreed with Mexico. As for the other arrangements with Poland and Colombia, the actual disbursements are still zero. The facility provides a contingent credit line with an ex-ante policy conditionality, without conditioning future disbursements on compliance with policy targets as in traditional IMF-supported programs. Transferring conditionality from the ex-post to the ex-ante phase of the arrangement limits the possible stigma of borrowing from the IMF, pushes candidate borrowers to reform and might restore investor confidence in the country's ability to deal with the crisis, catalyzing capital flows. Notwithstanding these positive effects, the limit of ex-ante policy conditionality, when too tight, is to limit the pool of eligible countries to those which already have the instruments to cope with adverse external shocks, possibly excluding from this kind of arrangement a number of countries, especially those needing it the most, such as SubSaharan African nations. Conditioning the qualification for the FCL to the presence of strong economic fundamentals and institutional policy frameworks, the Fund still rewards countries whose policies are closer to those prescribed by the "Washington Consensus" and persists in the old-fashioned stringent fiscal and monetary policies and controversial structural reforms (Eurodad, 2009) ${ }^{13}$. In any case, in all the three countries under the FCL the agreements reduced the CDS spreads, facilitating the securing of external finance, sustaining the exchange rates and providing resources for a fiscal stimulus (International Monetary Fund, 2009c).

The SDR 750 million SBA approved to Georgia, the strongest performer in Central Asia in the years before the crisis, is one of the largest loans in terms of national output. The exceptionality of this loan, which accounts for almost $500 \%$ of the quota and goes hand in-hand with a large EU aid intervention, is motivated by the twofold negative shock of the armed conflict with Russia of 2008 and the financial crisis, aiming to restore investor confidence and private sector-led economic growth. So far, progress are observable in terms of a stable exchange rate, narrowing spreads, higher bank lending and FDI inflows, even if the path to recovery is uncertain and highly dependent on the international scenario. To anticipate one of the arguments developed in the next section,

before 2008: Gabon (SBA, USD 124 million); Grenada, Sierra Leone, Afghanistan, Haiti, Mauritania, Central African Republic, Gambia, Burkina Faso, Nicaragua and Guinea (PRGF, USD 857 million in all).

${ }^{13}$ According to the official IMF guide to the FCL (International Monetary Fund, 2009a, p. 13, Table 1), the qualification criteria include: a sustainable external position; a capital account position dominated by private flows; a track record of steady sovereign access to capital markets at favorable terms, sound public finances; low and stable inflation, in the context of a sound monetary and exchange rate policy framework; absence of bank solvency problems that pose an imminent threat of a systemic banking crisis. 
the SBA agreed with Georgia and the FCL with Mexico, Colombia and Poland, together with the list of borrowing countries reported in Table 1, illustrate that economics is not the only driving factor of IMF loans. Political affinity with the IMF major shareholders and their strategic interests in developing countries also seem to affect IMF lending choices during this global crisis.

\section{What has driven participation in IMF loan pro- grams during the crisis?}

Much empirical research has been devoted to examining the motivations of the Fund and member countries for entering into a lending arrangement ${ }^{14}$. While results vary with the sample periods, countries, IMF programs, empirical models and econometric methods considered in the analysis, a common conclusion to all the studies is that the likelihood of a country participating in an IMF program and the amount agreed in the arrangement depends not only on the macroeconomic framework of the borrower, but also on its political conditions, lobbying capacity, affinity and strategic links with IMF large shareholders, political-economic interests of Western countries and on past lending experiences between the country and the Fund.

In the following, we consider a sample of 110 low- and middle-income countries ${ }^{15}$. Of these, 62 are classified by the Fund as PRGF-eligible ${ }^{16}$ : 30 are low-income, 29 lowermiddle income and three upper-middle income countries and, notwithstanding their PRGF-eligibility, six of them received a Stand-By Arrangement. By contrast, the sample of non-PRGF-eligible countries is made exclusively by middle-income countries, who gained or not access to an SBA or an FCL arrangement (see Figure 2).

Significant differences in some macroeconomic and institutional variables emerge across countries with or without an IMF loan in place (Table 2). Consistently with a large body of literature (Thacker, 1999; Bird and Rowlands, 2001; Barro and Lee, 2005; Ghosh et al., 2008), the former exhibit, on average, fewer international reserves and a larger current account deficit. Other macroeconomic characteristics, such as national output, per capita GDP, debt service and the inflation rate, are not significantly correlated with the participation in an IMF loan program in 2008 and 2009 (Bird and Rowlands, 2001; Vreeland, 2004). However, splitting the sample between PRGF-eligible and other low- and middleincome countries shows that the probability of getting a loan is significantly higher for countries with a lower per capita GDP in the former sample, while the opposite happens in the latter sample ${ }^{17}$. As regards the politics of IMF assistance, the amount of bilateral aid received by G-7 countries, which is widely used as a foreign policy instrument (Alesina and Dollar, 2000), and an index of political affinity with the United States are greater

\footnotetext{
${ }^{14}$ Joyce (2004), Bird (2007) Steinwand and Stone (2008) and Ghosh et al. (2008) provide comprehensive reviews of this literature.

${ }^{15}$ The income classification is taken from the World Bank, see its website at: http://go.worldbank.org/K2CKM78CC0. From the sub-sample of IMF loan recipients, we exclude Iceland and Hungary as high income countries and Liberia as an outlier, since the amount of the IMF loan is 45 percent of GDP (Table 1). We also drop from the control group countries which have an IMF loan arrangement in place started before 2008, since they cannot be targeted by new IMF loans.

${ }^{16}$ See the IMF website at: http://www.imf.org/external/np/exr/facts/prgf.htm.

${ }^{17}$ Results not shown for reasons of space.
} 
Table 1: IMF lending arrangements started in 2008-2009 (thousands of USD)

\begin{tabular}{|c|c|c|c|c|c|}
\hline \multicolumn{6}{|c|}{ Stand-By ArRangements (SBA) } \\
\hline Member & $\begin{array}{c}\text { Date of } \\
\text { Arrangement }\end{array}$ & $\begin{array}{l}\text { Date of } \\
\text { Expiration }\end{array}$ & $\begin{array}{l}\text { Total Amount } \\
\text { Agreed }\end{array}$ & $\begin{array}{l}\text { Undrawn } \\
\text { Balance }\end{array}$ & $\begin{array}{c}\text { Amount } \\
\text { Agreed/GDP }\end{array}$ \\
\hline Georgia & Sep 15, 2008 & Jun 14,2011 & $1,202,965$ & 587,072 & $9.35 \%$ \\
\hline Ukraine & Nov 5, 2008 & Nov 4,2010 & $17,711,980$ & $6,440,720$ & $9.86 \%$ \\
\hline Hungary & Nov 6, 2008 & Oct 5,2010 & $16,967,272$ & $4,670,327$ & $10.88 \%$ \\
\hline Seychelles & Nov 14, 2008 & Nov 13, 2010 & 28,339 & 14,170 & $3.46 \%$ \\
\hline Iceland & Nov 19,2008 & May 31,2011 & $2,254,252$ & $1,183,482$ & $13.43 \%$ \\
\hline Pakistan & Nov 24,2008 & Dec 30,2010 & $11,651,101$ & $6,172,247$ & $7.08 \%$ \\
\hline Latvia, Rep. of & Dec 23,2008 & Mar 22, 2011 & $2,450,092$ & $1,300,758$ & $7.21 \%$ \\
\hline Belarus, Rep. of & Jan 12, 2009 & Apr 11,2010 & $3,654,331$ & $1,410,291$ & $6.06 \%$ \\
\hline El Salvador & Jan 16,2009 & Mar 31, 2010 & 827,472 & 827,472 & $3.74 \%$ \\
\hline Serbia, Rep. of & Jan 16,2009 & Apr 15,2011 & $4,217,255$ & $3,087,633$ & $8.42 \%$ \\
\hline Armenia, Rep. of & Mar 6, 2009 & Jul 5, 2011 & 859,192 & 373,014 & $7.21 \%$ \\
\hline Mongolia & Apr 1, 2009 & Oct 1,2010 & 246,841 & 98,736 & $4.71 \%$ \\
\hline Costa Rica & Apr 11, 2009 & Jul 10, 2010 & 792,692 & 792,692 & $2.67 \%$ \\
\hline Guatemala & Apr 22, 2009 & Oct 21,2010 & $1,015,380$ & $1,015,380$ & $2.60 \%$ \\
\hline Romania & May 4, 2009 & May 3, 2011 & $18,425,290$ & $8,622,514$ & $9.21 \%$ \\
\hline Bosnia \& Herzegovina & Jul 8, 2009 & Jun 30,2012 & $1,633,689$ & $1,339,621$ & $8.85 \%$ \\
\hline Sri Lanka & Jul 24, 2009 & Mar 23, 2011 & $2,662,594$ & $1,996,945$ & $6.72 \%$ \\
\hline Dominican Republic & Nov 9, 2009 & Mar 8, 2012 & $1,762,342$ & $1,440,306$ & $3.97 \%$ \\
\hline Angola & Nov 23, 2009 & Feb 22, 2012 & $1,382,984$ & $1,014,188$ & $1.63 \%$ \\
\hline Total & & & $89,746,060$ & $42,387,567$ & $7.67 \%$ \\
\hline \multicolumn{6}{|c|}{ Flexible CRedit Line (FCL) } \\
\hline Member & $\begin{array}{c}\text { Date of } \\
\text { Arrangement }\end{array}$ & $\begin{array}{l}\text { Date of } \\
\text { Expiration }\end{array}$ & $\begin{array}{l}\text { Total Amount } \\
\text { Agreed }\end{array}$ & $\begin{array}{l}\text { Undrawn } \\
\text { Balance }\end{array}$ & $\begin{array}{c}\text { Amount } \\
\text { Agreed/GDP }\end{array}$ \\
\hline Mexico & Apr 17, 2009 & Apr 16, 2010 & $50,765,755$ & $50,765,755$ & $4.67 \%$ \\
\hline Poland, Rep. of & May 6, 2009 & May 5, 2010 & $22,043,364$ & $22,043,364$ & $4.18 \%$ \\
\hline Colombia & May 11,2009 & May 10,2010 & $11,216,514$ & $11,216,514$ & $4.66 \%$ \\
\hline Total & & & $84,025,633$ & $84,025,633$ & $4.53 \%$ \\
\hline \multicolumn{6}{|c|}{ Poverty Reduction and Growth Facility - (PRGF) } \\
\hline Member & $\begin{array}{c}\text { Date of } \\
\text { Arrangement }\end{array}$ & $\begin{array}{l}\text { Date of } \\
\text { Expiration }\end{array}$ & $\begin{array}{c}\text { Total Amount } \\
\text { Agreed }\end{array}$ & $\begin{array}{l}\text { Undrawn } \\
\text { Balance }\end{array}$ & $\begin{array}{c}\text { Amount } \\
\text { Agreed/GDP }\end{array}$ \\
\hline Liberia & Mar 14,2008 & Mar 13, 2011 & 384,865 & 28,597 & $45.28 \%$ \\
\hline Togo & Apr 21,2008 & Apr 20,2011 & 135,915 & 56,678 & $4.70 \%$ \\
\hline Mali & May 28,2008 & May 27,2011 & 45,069 & 12,881 & $0.51 \%$ \\
\hline Niger & Jun 2,2008 & Jun 1,2011 & 37,082 & 21,190 & $0.69 \%$ \\
\hline Zambia & Jun 4,2008 & Jun 3,2011 & 354,393 & 170,998 & $2.42 \%$ \\
\hline Burundi & Jul 7, 2008 & Jul 6, 2011 & 74,390 & 42,509 & $6.76 \%$ \\
\hline Djibouti & Sep 17, 2008 & Sep 16, 2011 & 20,481 & 11,883 & $2.09 \%$ \\
\hline Congo, Rep. of & Dec 8, 2008 & Dec 7, 2011 & 13,622 & 9,730 & $0.13 \%$ \\
\hline Sao Tome \& Principe & Mar 2, 2009 & Mar 1, 2012 & 4,170 & 3,575 & $2.32 \%$ \\
\hline Cote d'Ivoire & Mar 27, 2009 & Mar 26, 2012 & 602,175 & 345,596 & $2.56 \%$ \\
\hline Tajikistan, Rep. of & Apr 21, 2009 & Apr 20, 2012 & 126,077 & 84,051 & $2.45 \%$ \\
\hline Ghana & Jul 15, 2009 & Jul 14, 2012 & 623,864 & 514,936 & $3.75 \%$ \\
\hline Comoros & Sep 21, 2009 & Sep 20,2012 & 21,855 & 15,047 & $4.12 \%$ \\
\hline Total & & & $2,443,960$ & $1,317,671$ & $2.67 \%$ \\
\hline \multicolumn{6}{|c|}{ Exogenous Shocks FACILITY - (ESF) } \\
\hline Member & $\begin{array}{c}\text { Date of } \\
\text { Arrangement }\end{array}$ & $\begin{array}{c}\text { Date of } \\
\text { Expiration }\end{array}$ & $\begin{array}{l}\text { Total Amount } \\
\text { Agreed }\end{array}$ & $\begin{array}{l}\text { Undrawn } \\
\text { Balance }\end{array}$ & $\begin{array}{c}\text { Amount } \\
\text { Agreed/GDP }\end{array}$ \\
\hline Malawi & Dec 3, 2008 & Dec 2, 2009 & 83,810 & 27,937 & $1.96 \%$ \\
\hline Kyrgyz Rep. & Dec 10,2008 & Jun 9, 2010 & 107,238 & 53,619 & $2.12 \%$ \\
\hline Senegal & Dec 19,2008 & Jun 18,2010 & 195,395 & 104,211 & $1.46 \%$ \\
\hline Tanzania & May 29, 2009 & May 28,2010 & 352,291 & 96,079 & $1.70 \%$ \\
\hline Mozambique & Jun 30,2009 & Jun 29,2010 & 182,916 & 45,729 & $1.85 \%$ \\
\hline Ethiopia & Aug 26, 2009 & Oct 25,2010 & 247,573 & 129,169 & $0.94 \%$ \\
\hline Total & & & $1,169,224$ & 456,744 & $1.47 \%$ \\
\hline
\end{tabular}

Notes: Elaboration of IMF data, as of November 30, 2009. Original data in SDR are converted into USD at the November 30, 2009 official exchange rate (1.610180).

for countries participating in an IMF loan program. The latter correlation is driven exclusively by the sub-sample of non PRGF-eligible countries. That the closeness to US foreign policy especially benefits middle-income countries might be due to the greater geo-political role played by Balkan and Caucasian countries, as also suggested by the 
positive correlation between participation in the IMF loan program and per capita GDP. This evidence confirms the findings of a growing literature stressing the importance of the political proximity between the recipients and the IMF major shareholders on the Fund's lending policies (Bird and Rowlands, 2001; Barro and Lee, 2005; Eichengreen, Gupta and Mody, 2006; Stone, 2008). On the contrary, and in contrast with some evidence supporting the relevance of economic ties in shaping IMF lending (Barro and Lee, 2005; Pop-Eleches, 2009), there are no significant differences in the likelihood of getting a loan with respect to the G-7 economic interests in developing countries, measured as their debt to private creditors and their overall trade with G-7 countries.

Consistently with the "recidivism" of IMF borrowing countries (Bird, Hussain and Joyce, 2004; Atoyan and Conway, 2006), we find that IMF loan programs are pathdependent: current recipients received almost nine loans in the period 1990-2005, a figure significantly higher than the number of loans granted to non-borrowing countries. Finally, as regards the variable of interest, there is some weak evidence that the Fund has targeted countries where the extent of the crisis, measured as the difference in the cumulated GDP growth over the period 2008-2011 between the April 2008 and October 2009 WEO estimates, was statistically bigger (the one-tailed test is significant at 11 percent level of confidence).

This feeble result is further weakened by the evidence depicted in Figure 2, which provides a further analysis of the targeting of IMF loan programs with respect to the severity of the crisis. The upper panel considers the sample of PRGF-eligible countries, while the lower panel takes into consideration the sample of other low- and middle-income countries. In both cases, countries under an IMF arrangement do not systematically show a revision in growth rates larger than countries not targeted by the IMF. In fact, some of the former - Ghana, Ethiopia, and Niger - show a positive revision in GDP growth rates and some of the latter, notably Russia, Bulgaria, Moldova and Madagascar, are severely hit by the crisis, with a drop in GDP growth well above $20 \%$ with respect to the pre-crisis projections.

So far we have considered the relationship between the likelihood of participating in an IMF loan program and country characteristics. The diagrams reported in Figures 3,4 and 5 show the scatterplots of the amount of the agreed loan over GDP and different country characteristics, also plotting the regression line for the overall sample and for the subsample of PRGF-eligible countries. Figure 3 shows a clear positive correlation between loan size and the severity of the crisis in recipient countries, both in the overall sample and in the sub-sample of PRGF-eligible countries. Once again, Caucasian countries are well above the regression line suggesting that the response of IMF in these countries has been more intense than the average.

Coming to the other possible determinants of the amount of the Fund loan, diagrams (a) and (b) in Figure 4 consider the balance of payments and show that the lower the stock of international reserves and the higher the current account deficit, the larger is the loan agreed, as a share of GDP, consistently with the evidence discussed by Dreher and Vaubel (2004) and Barro and Lee (2005). Panel (c) points out the absence of any significant correlation between GDP and the amount of the loan, indicating that the IMF did not explicitly target big countries. Panel (d), instead, provides some weak evidence supporting the findings already discussed about the likelihood of getting the loan: among non PRGF-eligible countries, the Fund credit allocation seems to be biased towards richer 
Table 2: Variables: description, sources and sample means by participation in IMF programs.

\begin{tabular}{|c|c|c|c|}
\hline \multirow[t]{2}{*}{ DESCRIPTION } & \multicolumn{3}{|c|}{ SAMPLE MEANS } \\
\hline & No Program & IMF program & t-test \\
\hline $\begin{array}{l}\text { Country with a loan in place: dummy equal to one whether } \\
\text { the country agreed on an IMF loan in } 2008 \text { and } 2009 \text { and } \\
\text { zero otherwise. Source: IMF }\end{array}$ & \multicolumn{3}{|c|}{ Whole sample: 0.345} \\
\hline Loan size: amount of IMF credit (\% GDP). Source: IMF & 0.042 & 0.000 & NA \\
\hline $\begin{array}{l}\text { Extent of the crisis, measured as the difference in the } \\
\text { cumulated GDP growth over the period 2008-2011, between } \\
\text { the April } 2008 \text { and October } 2009 \text { estimates. Source: WEO } \\
\text { database (October } 2009 \text { and April 2008) }\end{array}$ & 0.091 & 0.115 & \\
\hline $\begin{array}{l}\text { Logarithm of GDP in } 2007 \text { (current USD). Source: World } \\
\text { Development Indicators (WDI) }\end{array}$ & 23.534 & 23.343 & \\
\hline GDP per capita in 2007 (current USD). Source: WDI & 3,237 & 3,020 & \\
\hline Current account balance (\% GDP) in 2007. Source: WDI & -0.041 & -0.083 & $* *$ \\
\hline $\begin{array}{l}\text { Total reserves in months of imports in 2007. Source: WDI } \\
\text { and national sources }\end{array}$ & 6.185 & 3.666 & $* * *$ \\
\hline Total debt service (\% GNI) in 2007. Source: WDI & 0.052 & 0.045 & \\
\hline $\begin{array}{l}\text { Inflation, average consumer prices (Annual percent change) } \\
\text { in 2007. Source: WEO database (October 2009) }\end{array}$ & 0.066 & 0.073 & \\
\hline $\begin{array}{l}\text { The number of years during which the country was under an } \\
\text { IMF loan program for at least five months between } 1990 \text { and } \\
\text { 2005. Source: Dreher (2006) }\end{array}$ & 6.028 & 8.789 & $* * *$ \\
\hline $\begin{array}{l}\text { Exports plus imports from G7 countries in } 2006 \text { (\%GDP). } \\
\text { Source: Barbieri, Keshk and Pollins (2009) and WDI }\end{array}$ & 0.203 & 0.204 & \\
\hline $\begin{array}{l}\text { Public and publicly guaranteed debt to private creditors (\% } \\
\text { GDP) in 2007. Source: GDF }\end{array}$ & 0.066 & 0.046 & \\
\hline $\begin{array}{l}\text { Official development assistance by G7 countries in } 2007 \text { (\% } \\
\text { GDP). Source: OECD-DAC and WDI }\end{array}$ & 0.014 & 0.026 & $* *$ \\
\hline $\begin{array}{l}\text { Voting similarity in the United Nations General Assembly } \\
\text { with the USA. Source: Gartzke (2007) }\end{array}$ & 0.081 & 0.181 & $*$ \\
\hline
\end{tabular}

Notes: Statistics are calculated on the sample of 110 low- and middle-income countries (see Table 3 in Annex 6), apart from variables for which there are missing values. The last column reports the statistical significance of a two-tailed test of the null hypothesis that the values of the explanatory variables are equal in program and non-program countries, with $* * *(* *)\left({ }^{*}\right)$ indicating statistical significance at $1 \%(5 \%)(10 \%)$ level. For loan size, the t-test is not-applicable (NA).

countries.

As regards the degree of political connections with G-7 countries, panel (a) in Figure 4 clearly shows a positive association between the voting similarity with the G-7 in the UN General Assembly by recipient countries and the amount of IMF loans. Consistent with the findings provided by Oatley and Yackee (2004) and Barro and Lee (2005), political affinity between recipients and the IMF major shareholders has a positive effect not only on the probability of loan approval, but also on its size. On the contrary, official aid does not go hand-in-hand with larger IMF loans, in contrast to the descriptive evidence on the probability of getting a loan (Table 2). This apparent contradiction could be explained by a possible substitution effect between official aid and IMF lending: the decision to assist a country is driven by similar (political) determinants, irrespective of the instrument 
Figure 2: The Financial crisis and the IMF lending arrangements in 2008-2009

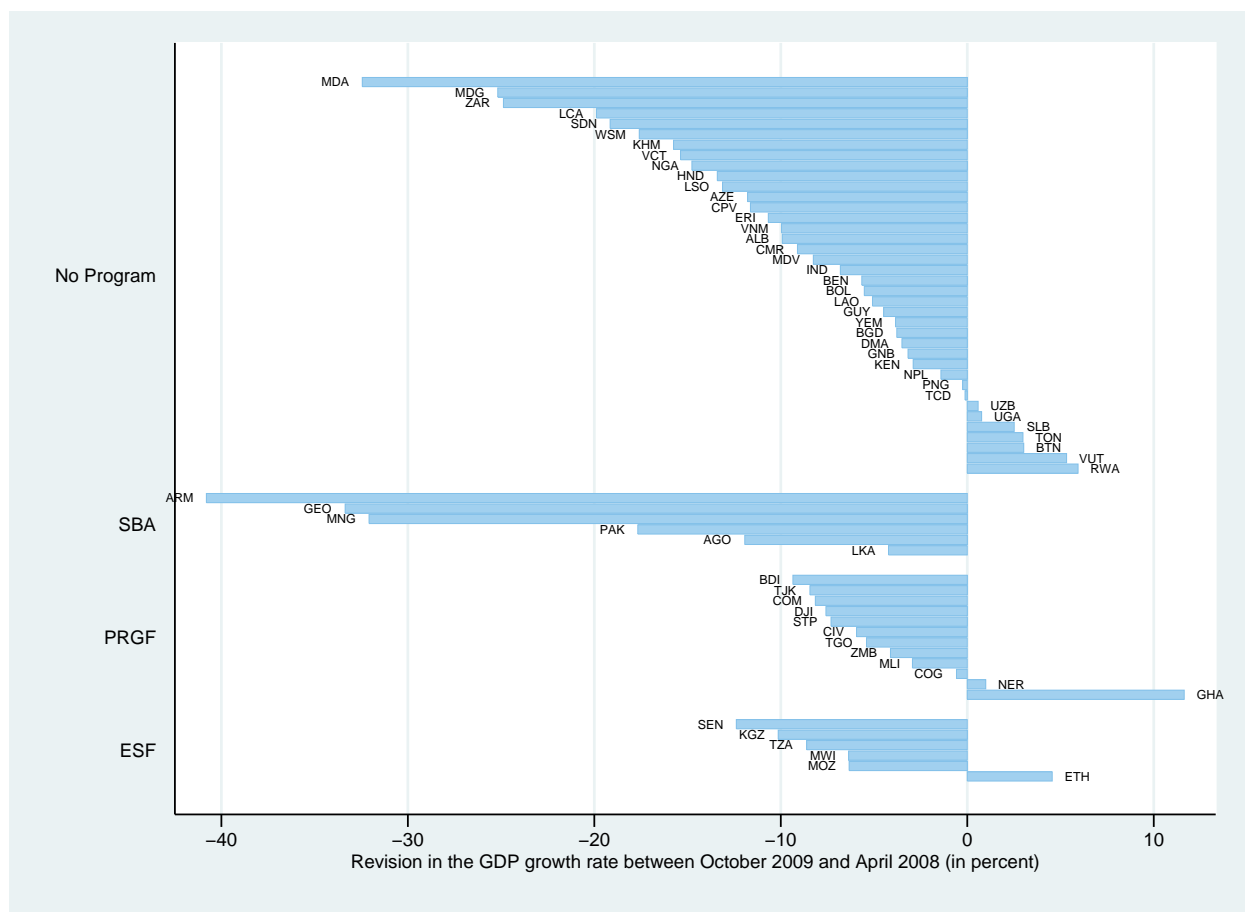

(a) PRGF-eligible Countries

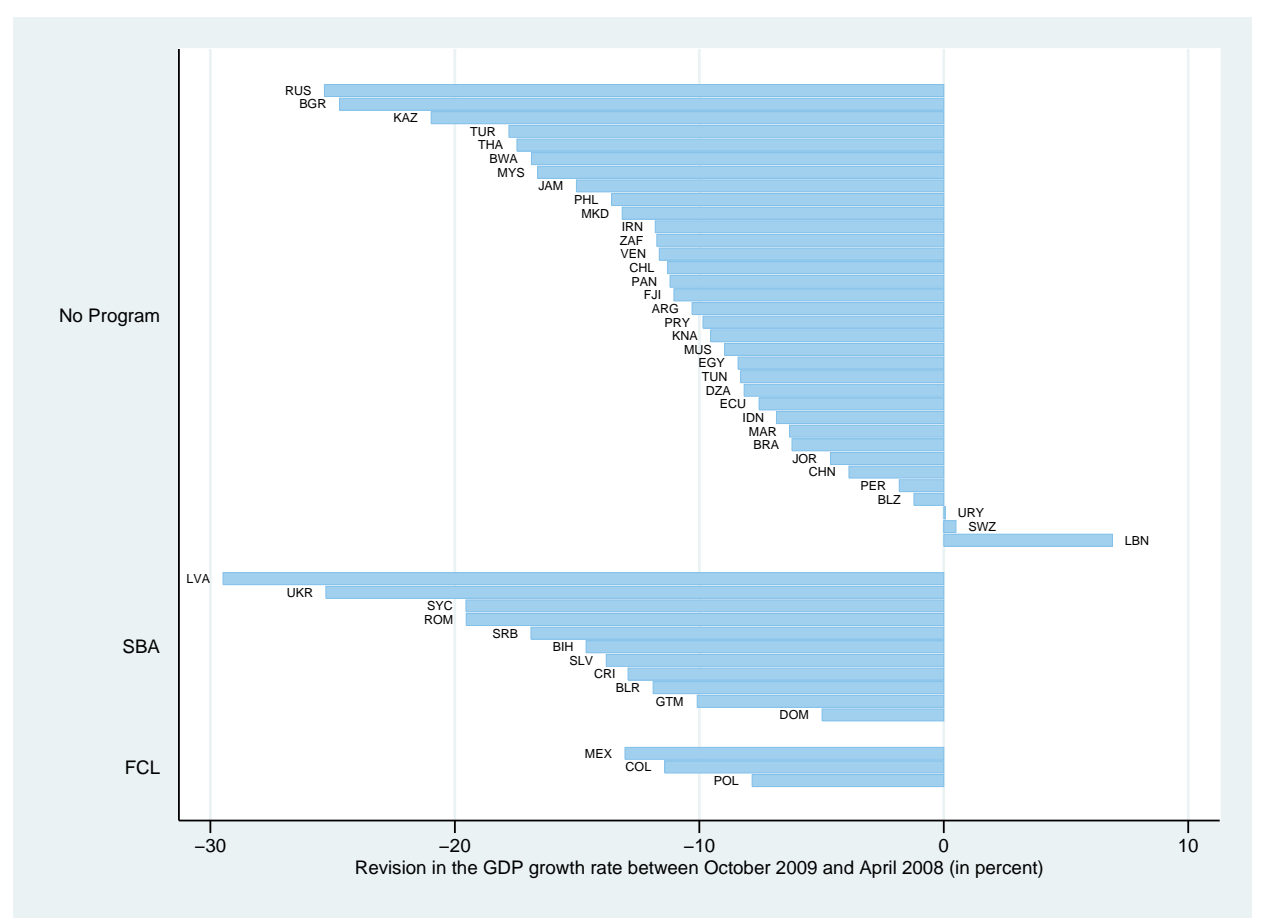

(b) Other middle-income countries

Notes: Elaboration of IMF data, as of November 30, 2009. The sample is made by 110 low- and middle-income countries, see Table 3 in Annex 6. The impact of the economic crisis is defined as the difference in the cumulated GDP growth over the period 2008-2011, between the October 2009 and April 2008 WEO estimates. 
adopted, but the actual disbursements are either in terms of aid or as IMF loans. Finally, the scatterplots in the lower panels do not indicate any strong association between the size of the loans granted by the Fund and the economic ties with G-7 countries, as measured by total merchandize trade and by the degree of indebtedness with private creditors. This contrasts with the evidence discussed by Barro and Lee (2005) on the positive effect of the intensity of trade with the US and Europe on loan size.

Figure 3: IMF lending and country characteristics

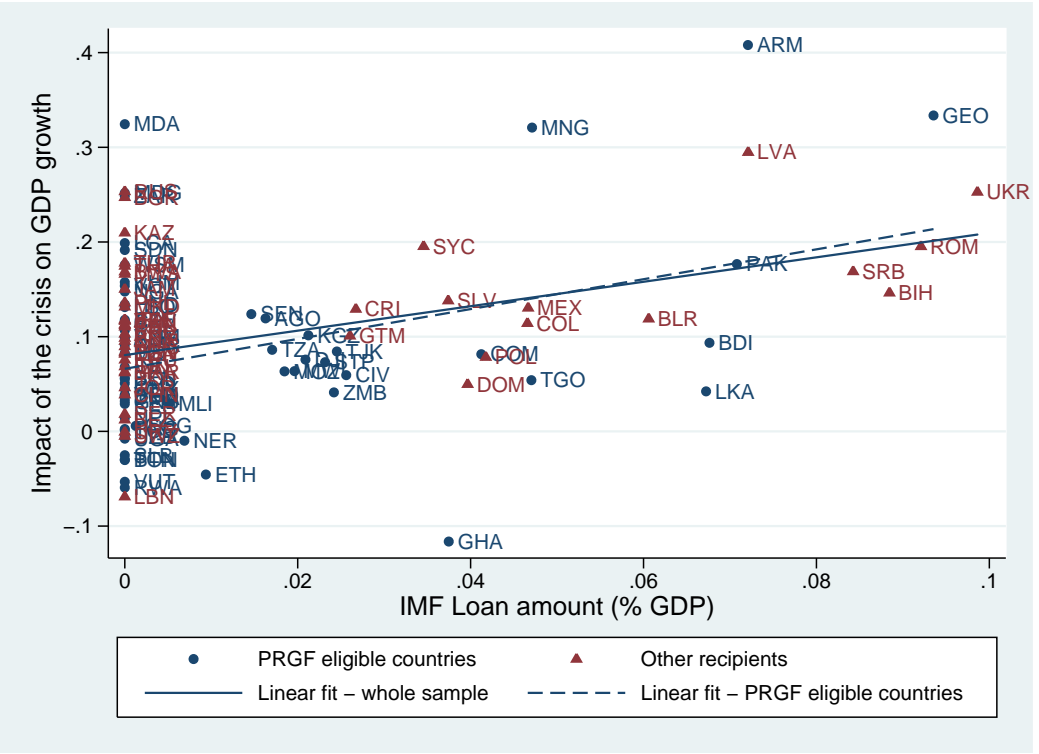

(a) Effect of the crisis on GDP growth rates

Notes: The diagram is drawn on the sample of 110 low- and middle-income countries (see Table 3 in Annex 6). 
Figure 4: IMF lending and country economic characteristics

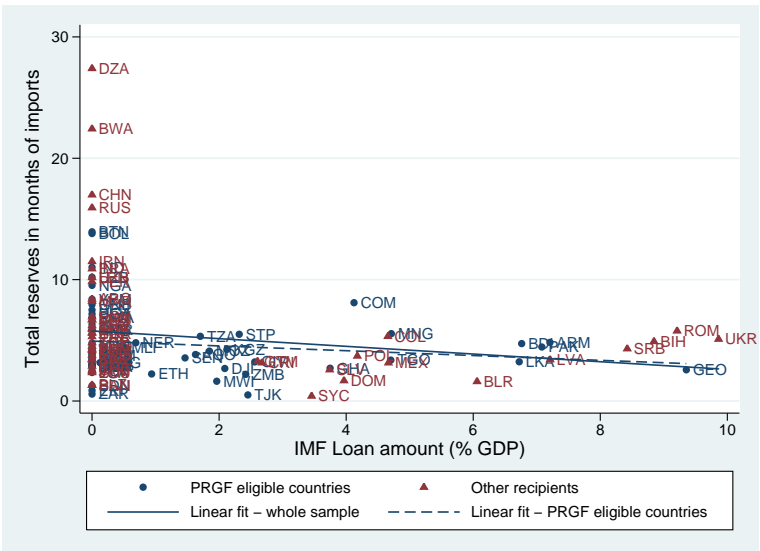

(a) Reserves (in months of imports) in 2007

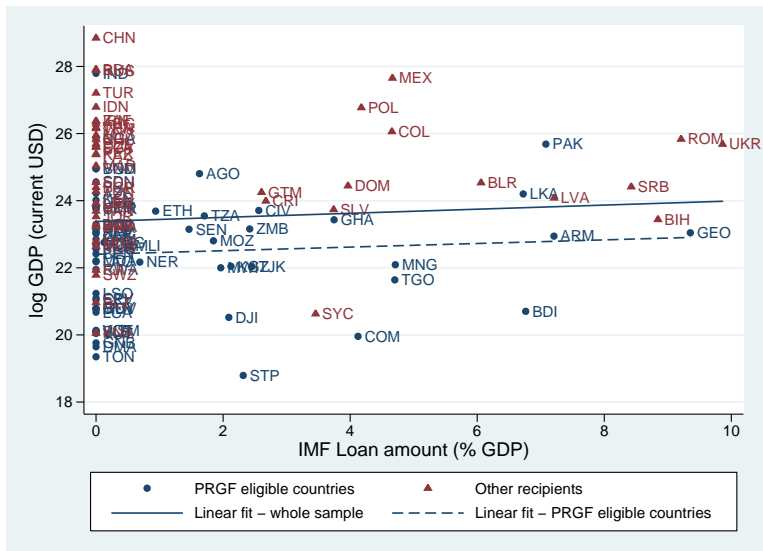

(c) Log of GDP (in current USD) in 2007

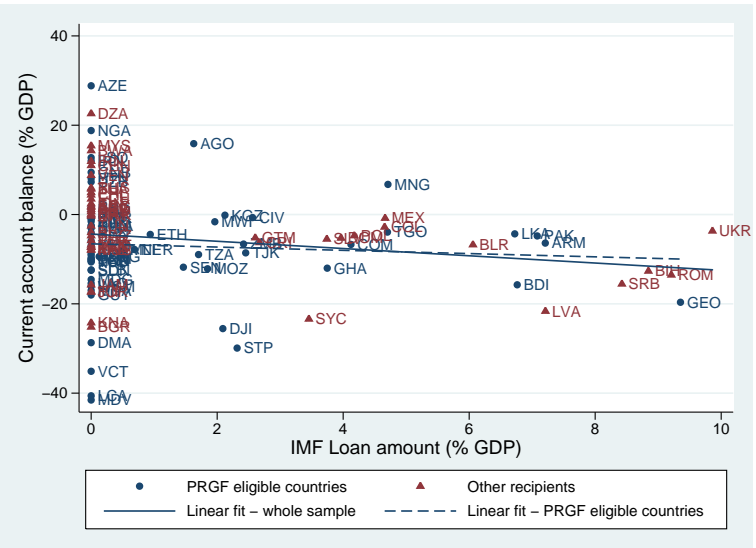

(b) Current account balance (\%GDP) in 2007

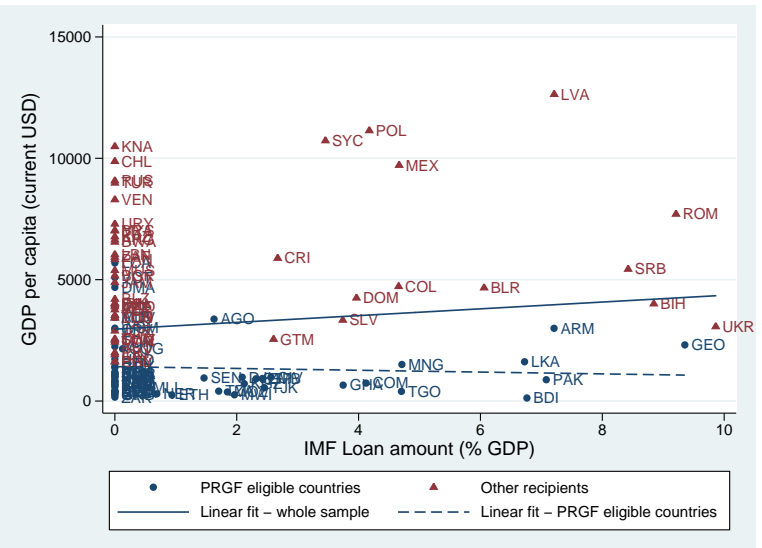

(d) Per capita GDP (in current USD) in 2007

Notes: Diagrams are drawn on the sample of 110 low- and middle-income countries (see Table 3 in Annex 6). 
Figure 5: IMF lending and political and economic proximity with G-7 countries

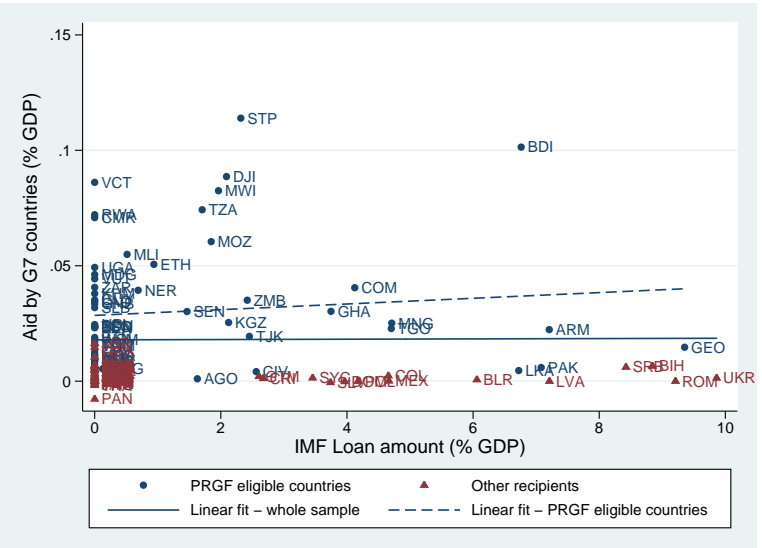

(a) Official aid from G-7 (\%GDP) in 2007

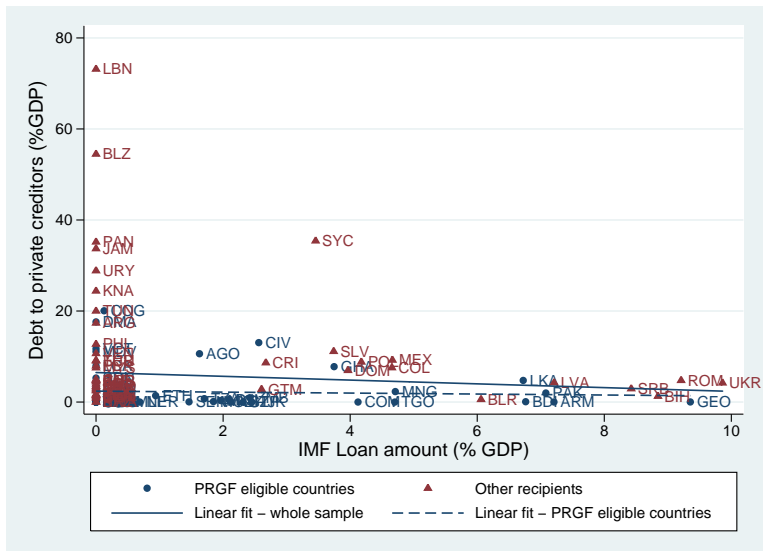

(c) Debt to private creditors (\%GDP) in 2007

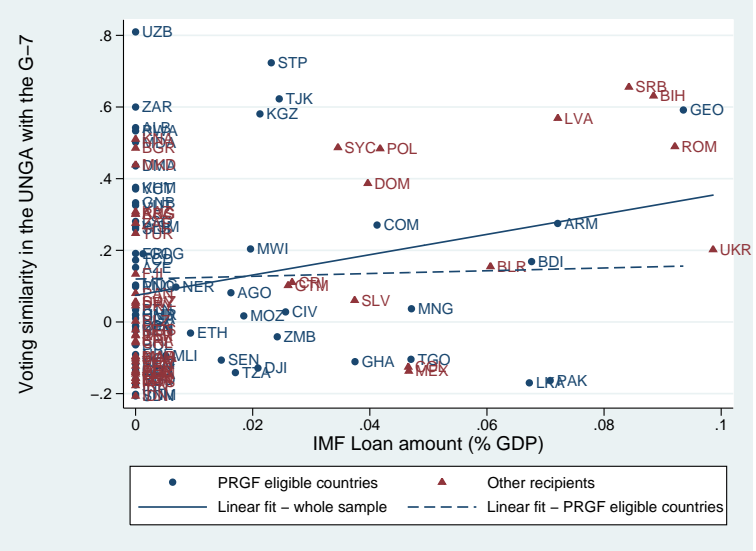

(b) Voting similarity with the USA

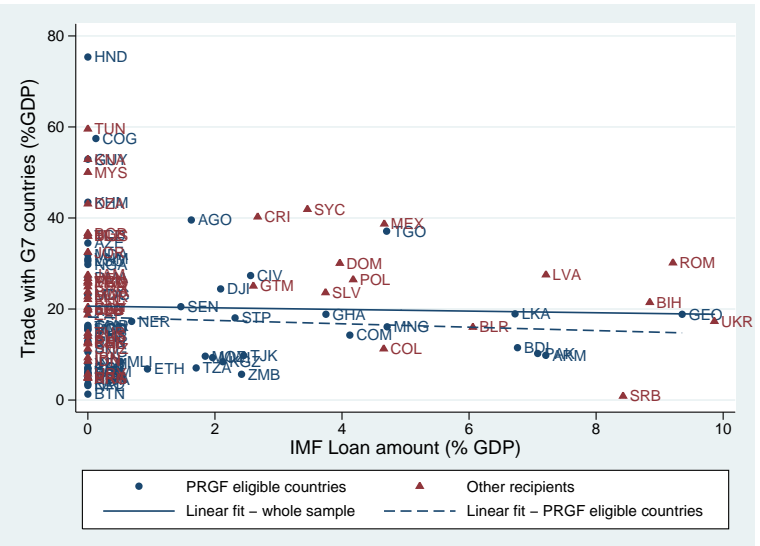

(d) Trade with G-7 countries (\%GDP) in 2006

Notes: Diagrams are drawn on the sample of 110 low- and middle-income countries (see Table 3 in Annex 6). 


\section{Concluding remarks}

Developing countries are the least to blame for the outbreak of the financial crisis, but they are destined to suffer the most dramatic and long-lasting consequences. A severe reduction in international trade due to a retrenchment in import demand in industrialized countries and a contraction in financial flows are the major contagion mechanisms that have spread the crisis to low- and middle-income countries. Due to a collapse in export revenues and capital inflows and of the limited room for countercyclical policies, a critical role in tackling the crisis in poor countries is going to be played by Western countries and by the International Financial Institutions. To avoid losing some of the hard-gained achievements in poverty reduction, developing countries will need additional financial assistance to tap an estimated financing gap of around 690 billion of dollars (World Bank, 2010). At recent summits donors have made a number of pledges, but a decadeslong experience of foreign assistance and the unmet target of delivering the $0.7 \%$ of GDP in development assistance recall the difference between commitments and actual disbursements.

With the unfolding of the crisis, the World Bank and IMF have developed different strategies aimed at mitigating the effects of the global recession, improving the lending capacity and the pool of resources available to developing countries. In particular, the IMF has responded to the crisis, increasing its lending capacity up to USD 750 billion and developing a new lending framework for developing countries. Nonetheless, as feared by several commentators (Stiglitz, 2010), out of USD 177 billion agreed for 41 lending arrangements started in 2008 and 2009 in response to the crisis, only two percent goes to poor (PRGF-eligible) countries.

Preliminary analysis of the 2008 and 2009 IMF arrangements shows that the severity of the economic crisis in developing countries appears to influence the Fund's lending policies, especially with respect to the amount of credit agreed. However, the participation in the IMF loan programs is only weakly correlated with the intensity of the downturn. A more decisive role is played, as in past experiences, by "recidivism", balance of payments problems and economic ties and political affinity with the IMF major shareholders. On the whole, notwithstanding the recent changes in the lending framework and the severity of the global crisis, IMF credit allocation is still mainly driven by the strategic interests of Western countries, instead of the macroeconomic conditions of recipients.

As we are writing, thanks to massive interventions by the fiscal and monetary authorities in industrialized countries, the confidence in global financial markets is partly restored and the liquidity injections are easing financing constraints also for emerging and developing countries, limiting the prospects for future uses of IMF assistance. Nonetheless, the recent downgrade of Mexico and Greece credit ratings and the standstill on debt payment requested by Dubai World suggest that we are not yet beyond the crisis. Large deficits in many low-income countries and burgeoning public debts are a source of concern for future debt sustainability (Presbitero, 2009). Moreover, excessive global liquidity might translate into another asset bubble, which would represent a serious threat to poor countries vulnerable to capital flight. 


\section{References}

Alesina, Alberto and David Dollar. 2000. "Who Gives Foreign Aid to Whom and Why?" Journal of Economic Growth 5(1):33-63.

Atoyan, Ruben and Patrick Conway. 2006. "Evaluating the impact of IMF programs: A comparison of matching and instrumental-variable estimators." Review of International Organizations 1(2):99-124.

Barbieri, Katherine, Omar Keshk and Brian Pollins. 2009. "TRADING DATA: Evaluating our Assumptions and Coding Rules." Conflict Management and Peace Science Forthcoming.

Barro, Robert J. and Jong-Wha Lee. 2005. "IMF programs: Who is chosen and what are the effects?" Journal of Monetary Economics 52(7):1245-1269.

Berg, Andrew, Norbert Funke, Alejandro Hajdenberg, Victor Lledo, Rolando Ossowski, Martin Schindler, Antonio Spilimbergo, Shamsuddin Tareq and Irene Yackovlev. 2009. Fiscal Policy in Sub-Saharan Africa in Response to the Impact of the Global Crisis. IMF Staff Position Note 09/10 International Monetary Fund.

Berger, Allen N., Leora F. Klapper and Gregory F. Udell. 2001. "The ability of banks to lend to informationally opaque small businesses." Journal of Banking \& Finance 25(12):2127-2167.

Bird, Graham. 2007. "The IMF: A Bird'S Eye View of Its Role and Operations." Journal of Economic Surveys 21(4):683-745.

Bird, Graham and Dane Rowlands. 2001. "IMF Lending: How Is It Affected by Economic, Political, and Institutional Factors?" Journal of Policy Reform 4(2):243-270.

Bird, Graham, Mumtaz Hussain and Joseph P. Joyce. 2004. "Many happy returns? Recidivism and the IMF." Journal of International Money and Finance 23(2):231-251.

Dang, Hai-Anh, Steve Knack and Halsey Rogers. 2009. International aid and financial crises in donor countries. Policy Research Working Paper Series 5162 The World Bank.

De Rienzo, Paolo. 2009. "The G8 and poor countries: promises, just promises?" available via the internet at: http://www.globaleconomicgovernance.org/blog/2009/07/the-g8and-poor-countries-promises-justpromises/.

Detragiache, Enrica, Thierry Tressel and Poonam Gupta. 2008. "Foreign Banks in Poor Countries: Theory and Evidence." Journal of Finance 63(5):2123-2160.

Dreher, Axel. 2006. "IMF and economic growth: The effects of programs, loans, and compliance with conditionality." World Development 34(5):769-788.

Dreher, Axel. 2009. "IMF conditionality: theory and evidence." Public Choice 141(1):233-267. 
Dreher, Axel and Nathan M. Jensen. 2007. "Independent actor or agent? An empirical analysis of the impact of the US interests on IMF conditions." Journal of Law and Economics 50(1):105-124.

Dreher, Axel and Roland Vaubel. 2004. "Do IMF and IBRD Cause Moral Hazard and Political Business Cycles? Evidence from Panel Data." Open Economies Review 15(1):522 .

Dreher, Axel and Stefanie Walter. 2010. "Does the IMF Help or Hurt? The Effect of IMF programs on the likelihood and outcome of currency crises." World Development $38(1): 1-18$.

Eichengreen, Barry J., Poonam Gupta and Ashoka Mody. 2006. Sudden Stops and IMFSupported Programs. IMF Working Papers 06/101 International Monetary Fund.

Eurodad. 2009. "Bail-out or blow-out? IMF policy advice and conditions for low-income countries at a time of crisis." European Network on Debt and Development.

Food and Agriculture Organization. 2009. The State of Food Insecurity in the World. Rome: United Nations.

Fratianni, Michele and John Pattison. 2005. Who is running the IMF? Critical shareholders or the staff? In Multidisciplinary economics: the birth of a new economics faculty in the Netherlands, ed. P de Gijsel and H. Schenk. Berlin: Springer pp. 279-292.

Frot, Emmanuel. 2009. The Consequences of Financial Crises on Aid. mimeo SITE/Stockholm School of Economics.

Gartzke, Erik. 2007. "The Capitalist Peace." American Journal of Political Science 51(10):166-191.

Ghosh, Atish, Manuela Goretti, Bikas Joshi, Alun Thomas and Juan Zalduendo. 2008. "Modeling Aggregate Use of IMF Resources - Analytical Approaches and MediumTerm Projections." IMF Staff Papers 55(1):1-49.

Gormley, Todd A. 2010. "The impact of foreign bank entry in emerging markets: Evidence from India." Journal of Financial Intermediation 19(1):26-51.

Green, Duncan, Richard King and May Miller-Dawkins. 2010. "The Global Economic Crisis and Developing Countries: Impact and Response.".

Hajro, Zlata and Joseph Joyce. 2009. "A true test: do IMF programs hurt the poor?" Applied Economics 41(3):295-306.

Harrigan, Jane, Chengang Wang and Hamed El-Said. 2006. "The Economic and Political Determinants of IMF and World Bank Lending in the Middle East and North Africa." World Development 34(2):247-270.

Ilzetzki, Ethan and Carlos A. Vegh. 2008. Procyclical Fiscal Policy in Developing Countries: Truth or Fiction? NBER Working Papers 14191 National Bureau of Economic Research, Inc. 
International Financial Institution Advisory Commission. 2000. "Final Report." US Congress.

International Labour Office. 2010. Global Employment Trends. Geneva: United Nations.

International Monetary Fund. 2009a. The Flexible Credit Line - Guidance on Operational Issues. Policy papers International Monetary Fund.

International Monetary Fund. 2009b. Regional Economic Outlook - Sub-Saharan Africa. Washington, DC: International Monetary Fund.

International Monetary Fund. 2009c. Review of Recent Crisis Programs. Policy papers International Monetary Fund.

International Monetary Fund. 2009d. The Implication of the Global Financial Crisis for Low-Income Countries. Washington DC: International Monetary Fund.

International Monetary Fund. 2009e. The Implications of the Global Financial Crisis for Low-Income Countries: An Update. Policy papers International Monetary Fund.

Joyce, Joseph P. 2004. "Adoption, Implementation and Impact of IMF Programmes: A Review of the Issues and Evidence." Comparative Economic Studies 46(3):451-467.

Marangos, John. 2009. "The Evolution Of The Term 'Washington Consensus'." Journal of Economic Surveys 23(2):350-384.

Mold, Andrew, Sebastian Paulo and Annalisa Prizon. 2009. Taking Stock of the Credit Crunch: Implications for Development Finance and Global Governance. OECD Development Centre Working Papers 277 OECD, Development Centre.

Nsouli, Saleh M., Ruben Atoyan and Alex Mourmouras. 2006. Institutions, Program Implementation, and Macroeconomic Performance. Washington, DC: International Monetary Fund chapter 9, pp. 140-159.

Oatley, Thomas and Jason Yackee. 2004. "American Interests and IMF Lending." International Politics 41(3):415-29.

Pallage, Stéphane, Michel A Robe and Catherine Bérubé. 2006. "The Potential of Foreign Aid as Insurance." IMF Staff Papers 53(3):5.

Peek, Joe and Eric S Rosengren. 1997. "The International Transmission of Financial Shocks: The Case of Japan." American Economic Review 87(4):495-505.

Pop-Eleches, Grigore. 2009. From Economic Crisis to Reform: IMF Programs in Latin America and Eastern Europe. Princeton, New Jersey: Princeton University Press.

Presbitero, Andrea F. 2009. "The 2008-2009 Financial Crisis and the HIPCs: Another Debt Crisis?" Rivista Bancaria - Minerva Bancaria LXV(5-6):35-64.

Ratha, Dilip, Sanket Mohapatra and Ani Silwal. 2009. Migration and Remittance Trends 2009. Migration and Development Brief 11 The World Bank. 
Reinhart, Carmen and Vincent Reinhart. 2009. Fiscal stimulus for debt intolerant countries? MPRA Paper 16937 University Library of Munich, Germany.

Roodman, David. 2008. "History Says Financial Crisis Will Suppress Aid." Global Development: Views from the Center, available at: http://blogs.cgdev.org/globaldevelopment/2008/10/history-says-financial-crisis.php.

Steinwand, Martin C. and Randall W. Stone. 2008. "The International Monetary Fund: A review of the recent evidence." Review of International Organization 3(2):123-149.

Stiglitz, Joseph E. 2002. Globalization and Its Discontents. New York: W. W. Norton \& Company.

Stiglitz, Joseph E. 2010. Freefall - Free Markets and the Sinking of the Global Economy. London: Allen Lane.

Stone, Randall W. 2008. "The Scope of IMF Conditionality." International Organization 62(4):589-629.

Strauss-Kahn, Dominique. 2009. "The Impact of the Financial Crisis on Low-Income Countries." The Brookings Institution, Washington DC, available via the internet at: http: //www.brookings.edu//media/Files/events/2009/0303 ${ }_{i}$ ff/20090303 ${ }_{i}$ mf.pdf.

Thacker, Strom Cronan. 1999. "The High Politics of IMF Lending." World Politics $52(10): 38-75$.

UNCTAD. 2009. Trade and Development Report 2009. New York and Geneva: United Nations.

UNCTAD. 2010. Global Investment Trends Monitor. Geneva: United Nations.

United Nations. 2009. The Millennium Development Goals Report. New York: United Nations.

United Nations. 2010. World Economic Situation and Prospects 2010. New York: United Nations.

Van Rijckeghem, Caroline and Beatrice Weder. 2003. "Spillovers through banking centers: a panel data analysis of bank flows." Journal of International Money and Finance $22(4): 483-509$.

Vreeland, James Raymond. 2004. "Institutional Determinants of IMF Arrangements." Yale University.

Williamson, John. 1990. What Washington Means by Policy Reform. In Latin American Adjustment: How Much Has Happened, ed. John Williamson. Washington, DC: Institute for International Economics pp. 7-20.

Williamson, John. 2004. A Short History of the Washington Consensus. Paper commissioned by Fundación CIDOB for a conference "From the Washington Consensus towards a new Global Governance", Barcelona, September 24-25, 2004. 
World Bank. 2009. "Protecting Progress: The Challenge Facing Low-Income Countries in the Global Recession." September.

World Bank. 2010. Global Economic Prospects. Washington, DC: The World Bank.

World Food Program. 2010. Trends of staple food prices in vulnerable countries. The Market Monitor 6 United Nations.

Zoellick, Robert B. 2009. "Roundtable with Media." G7 Finance Minister Meeting, Rome, available via the internet at: http://go.worldbank.org/0YHVV64T90. 
A Additional tables 
Table 3: Sample of low- and middle-income countries

\begin{tabular}{|c|c|c|c|c|c|c|c|}
\hline Country & Code & $\begin{array}{c}\text { In- } \\
\text { come }\end{array}$ & IMF program & Country & Code & $\begin{array}{c}\text { In- } \\
\text { come }\end{array}$ & IMF program \\
\hline Angola & AGO & LMIC & SBA & Latvia & LVA & UMIC & SBA \\
\hline Albania & ALB & LMIC & .. & Morocco & MAR & LMIC & .. \\
\hline Argentina & ARG & UMIC & .. & Moldova & MDA & LMIC & .. \\
\hline Armenia & ARM & LMIC & SBA & Madagascar & MDG & LIC & .. \\
\hline Azerbaijan & $\mathrm{AZE}$ & LMIC & .. & Maldives & MDV & LMIC & .. \\
\hline Burundi & BDI & LIC & PRGF & Mexico & MEX & UMIC & FCL \\
\hline Benin & BEN & LIC & .. & Macedonia & MKD & UMIC & .. \\
\hline Bangladesh & BGD & LIC & .. & Mali & MLI & LIC & PRGF \\
\hline Bulgaria & BGR & UMIC & .. & Mongolia & MNG & LMIC & SBA \\
\hline Bosnia \& Herzegovina & BIH & UMIC & SBA & Mozambique & $\mathrm{MOZ}$ & LIC & ESF \\
\hline Belarus & BLR & UMIC & SBA & Mauritius & MUS & UMIC & .. \\
\hline Belize & BLZ & LMIC & .. & Malawi & MWI & LIC & ESF \\
\hline Bolivia & BOL & LMIC & .. & Malaysia & MYS & UMIC & .. \\
\hline Brazil & BRA & UMIC & .. & Niger & NER & LIC & PRGF \\
\hline Bhutan & BTN & LMIC & .. & Nigeria & NGA & LMIC & .. \\
\hline Botswana & BWA & UMIC & .. & Nepal & NPL & LIC & .. \\
\hline Chile & CHL & UMIC & .. & Pakistan & PAK & LMIC & SBA \\
\hline China & $\mathrm{CHN}$ & LMIC & .. & Panama & PAN & UMIC & .. \\
\hline Côte d'Ivoire & CIV & LMIC & PRGF & Peru & PER & UMIC & .. \\
\hline Cameroon & CMR & LMIC & .. & Philippines & PHL & LMIC & .. \\
\hline Congo, Rep. of & $\mathrm{COG}$ & LMIC & PRGF & Papua New Guinea & PNG & LMIC & .. \\
\hline Colombia & COL & UMIC & FCL & Poland & POL & UMIC & FCL \\
\hline Comoros & $\mathrm{COM}$ & LIC & PRGF & Paraguay & PRY & LMIC & .. \\
\hline Cape Verde & CPV & LMIC & .. & Romania & ROM & UMIC & SBA \\
\hline Costa Rica & CRI & UMIC & SBA & Russia & RUS & UMIC & .. \\
\hline Djibouti & DJI & LMIC & PRGF & Rwanda & RWA & LIC & .. \\
\hline Dominica & DMA & UMIC & .. & Sudan & SDN & LMIC & .. \\
\hline Dominican Rep. & DOM & UMIC & SBA & Senegal & SEN & LIC & ESF \\
\hline Algeria & DZA & UMIC & .. & Solomon Islands & SLB & LMIC & .. \\
\hline Ecuador & $\mathrm{ECU}$ & LMIC & .. & El Salvador & SLV & LMIC & SBA \\
\hline Egypt & EGY & LMIC & .. & Serbia & SRB & UMIC & SBA \\
\hline Eritrea & ERI & LIC & .. & São Tomé \& Príncipe & STP & LMIC & PRGF \\
\hline Ethiopia & ETH & LIC & ESF & Swaziland & SWZ & LMIC & .. \\
\hline Fiji & FJI & UMIC & .. & Seychelles & $\mathrm{SYC}$ & UMIC & SBA \\
\hline Georgia & GEO & LMIC & SBA & Chad & TCD & LIC & .. \\
\hline Ghana & GHA & LIC & PRGF & Togo & TGO & LIC & PRGF \\
\hline Guinea-Bissau & GNB & LIC & .. & Thailand & THA & LMIC & .. \\
\hline Guatemala & GTM & LMIC & SBA & Tajikistan & TJK & LIC & PRGF \\
\hline Guyana & GUY & LMIC &.. & Tonga & TON & LMIC &.. \\
\hline Honduras & HND & LMIC & .. & Tunisia & TUN & LMIC & .. \\
\hline Indonesia & IDN & LMIC & .. & Turkey & TUR & UMIC & .. \\
\hline India & IND & LMIC & .. & Tanzania & TZA & LIC & ESF \\
\hline Iran & IRN & LMIC & .. & Uganda & UGA & LIC & .. \\
\hline Jamaica & JAM & UMIC & .. & Ukraine & UKR & LMIC & SBA \\
\hline Jordan & JOR & LMIC & .. & Uruguay & URY & UMIC & .. \\
\hline Kazakhstan & $\mathrm{KAZ}$ & UMIC & .. & Uzbekistan & UZB & LIC & .. \\
\hline Kenya & KEN & LIC & .. & St. Vincent \& Gren. & VCT & UMIC & .. \\
\hline Kyrgyz Rep. & KGZ & LIC & ESF & Venezuela & VEN & UMIC & .. \\
\hline Cambodia & KHM & LIC & .. & Vietnam & VNM & LIC & .. \\
\hline St. Kitts \& Nevis & KNA & UMIC & .. & Vanuatu & VUT & LMIC & .. \\
\hline Laos & $\mathrm{LAO}$ & LIC & .. & Samoa & WSM & LMIC & .. \\
\hline Lebanon & LBN & UMIC & .. & Yemen, Rep. of & YEM & LIC & .. \\
\hline St. Lucia & LCA & UMIC & .. & South Africa & $\mathrm{ZAF}$ & UMIC & .. \\
\hline Sri Lanka & LKA & LMIC & SBA & Congo, Dem. Rep. of & ZAR & LIC & .. \\
\hline Lesotho & $\mathrm{LSO}$ & LMIC & .. & Zambia & $\mathrm{ZMB}$ & LIC & PRGF \\
\hline
\end{tabular}

Notes: The income classification is taken from the World Bank, see its website at: http://go.worldbank.org/K2CKM78CC0. The list of the IMF loan programs started in 2008 and 2009, at November 30, 2009, is available at: http://www.imf.org/external/np/fin/tad/extarr11.aspx?memberKey1=ZZZZdate1key=2009-11-30. 